\title{
THE INFORMATION SEEKING BEHAVIOUR MODEL OF IPB UNIVERSITY STUDENTS BASED ON STRUCTURAL EQUATION MODELLING
}

\author{
${ }_{1}^{1}$ janti Gristinawati Sujana, ${ }^{2}$ pudji Muljono, ${ }^{3}$ djuara P. Lubis, \\ ${ }^{4}$ sulistyo-Basuki \\ ${ }^{1}$ Doctoral Candidates in Department of Agricultural and Rural Development Communication at \\ Bogor Agricultural University \\ 2 Professor of Communication Science and Community Development at Bogor Agricultural University \\ ${ }^{3}$ Lecturer of Communication Science and Community Development at Bogor Agricultural University \\ ${ }^{4}$ Professor of Library Science Department at University of Indonesia \\ E-mail: 1jantigs@gmail.com, ${ }^{2}$ pudjimuljono@gmail.com, ${ }^{3}$ djuaralubis@gmail.com, sbasuki@indosat.net.id
}

\begin{abstract}
The abundant of information on the internet has become a competitor for libraries as information service providers. Therefore to survive and thrive, the libraries must change and adopt to a rapidly evolving external environment. Understanding user information seeking behaviour is very useful for redesigning various services that suit to user needs. The objectives of this study were: 1 ). To analyze the characteristics of digital natives and digital immigrants of IPB University students related to their information seeking behaviour; 2). To develop a model of information seeking behaviour of both digital natives and digital immigrants of IPB University students based on structural equation modeling. The study was mainly quantitative and questionnaire was designed to study students' information-seeking behaviour. The findings showed that the dominant behaviours and preferences of digital natives in their information seeking behaviour were influenced by environmental variables, especially the availability of information. For the information seeking behaviour variables of students, the dominant indicator were asking for printed and digital information to the lecturer. While for immigrant digital students their information seeking behaviour were dominantly influenced by environmental variables, especially the availability of information. The indicators for information seeking behaviour of digital immigrant student were dominated by asking printed information to friends, and requesting digital information to the lecturer. The success of getting information is dominant in the speed-of-getting-information indicator, both for digital natives and digital immigrant students.
\end{abstract}

\section{Introduction}

The rapid development of information and communication techno-logy has changed the way of human life. The abundant information engulf the human life, both useful and misleading information comes from various parts of the world. The more sophisticated mobile phones with various applications make information so easy to reach in a very fast time.

In the process of learning the students must be supported by appropriate information, they should not rely only to the knowledge they had gained from the lectures. They must acquire additional knowledge by reading books, proceedings, research reports and journals provided by the library. It has traditionally been seen that the library as the 'heart of the university' serving the academic community of its parent institution. However, the existence of the internet with abundant information has brought a lot of changes in the library and information services. Do students still need library services in the digital age? Accorrding to Liu et al. (2018), the 
internet is the main source of information used by students, even for college assignments. The use of search engines is very dominant even for academic scientific tasks that require a high level of knowledge. This is in accordance with Uses and Gratification Theory created by Katz, Blumler and Gurevitch (in West and Turner 2013), which says that people actively look for certain media and certain content to produce certain satisfaction. When someone needs information, by using a search engine as if all information is obtained the answer, regardless of the quality of the information source.

Libraries in this digital era must introspect and undergo great changes in their structure, manner and service due to the fast advancement of information technology. The abundance of information has changed the nature of libraries everywhere, cause reorganization of libraries into the lowering position in their parent organizations or even eliminating them. Libraries everywhere are under threat, the decline in visitors to the library and the limited available funds caused the closure of nearly 130 public libraries in Britain throughout 2017 (Cain, 2018). Therefore, Allen \& Taylor's (2017) stated that libraries must be physically rethought and set new goals while redefining their virtual space. There must be incentives for digital natives to go to the library or Learning Centre, hubs where colleagues can meet, work and develop communication skills.

To survive in the digital age and stay relevant, IPB University as one of the leading university in Indonesia, must find solutions to new challenges, overhaul many of their entrenched business processes, and foster systems that engage students. It is therefore necessary to know in advance how the information seeking behaviour of IPB University students, how they overcome obstacles to satisfy their information needs. This study attempts to investigate the information behaviours of IPB University students in their need to remain productive and informed and discover any obstacles they may face in retrieving their information needs. "Information seeking is a concious effort to acquire information in response to a need or gap in your knowledge" (Case, 2012), while according to Ford (2015) "Information seeking is a broader concept, embracing strategies a person devises in order to find information, which may include - but is not limited to searching. It may include the selection and use of a variety of search tools, and the use of other strategies such as browsing and monitoring". Information seeking behavior can influence student work, research and innovation (Zhong et al., 2018). As we understand currently the library should serve both digital natives and digital immigrant users, this study will differentiate the characteristic of both users in their information searching. The objectives of this study were: 1) To analyze the information seeking behaviour of IPB University students based on the generation of digital natives and digital immigrants; 2). To develop models of information seeking behaviour on digital natives and digital immigrant IPB University students based on structural equation modeling.

\section{Materials and Methods}

The population of the study was students of IPB University, which at the time of the data collection they were officially registered as students. The target population of this study comprises of both the undergraduates and the graduates studies (Masters and Doctoral Degree Programs). IPB University (Indonesian: Institut Pertanian Bogor, abbreviated as IPB) is a state-run agricultural university based in the city of Bogor, West Java Province, Indonesia. A total of 363 respondents selected through proportional stratified random sampling, 66.39 percent were digital natives and 33.61 percent were digital immigrants. 
The instruments used to collect data for this study were questionnaires and interview. The pre-test questionnaires were tested for its reliability and validity using the product moment correlation formula, and the reliability test used Cronbach's Alpha. Analysis of the collected data were based on Structural Equation Modeling (SEM). The variables in this study were developed based on the model of "information need and seeking" from Wilson (1999), and the "information search process" model from Kuhlthau (2016), accompanied by adjustments to the current situation where the use of information and communication technology in libraries was very high. Included in the variables were individual characteristics (X1), the ability to use search tools (X2), environment (X3), and information literacy (X4), allegedly affecting the seeking behaviour of printed information (Y11), digital information (Y12), and at the ends allegedly affecting the success of getting information (Y2).

\section{Results}

Data processing using SEM for IPB University digital natives students are presented in Figure 1.

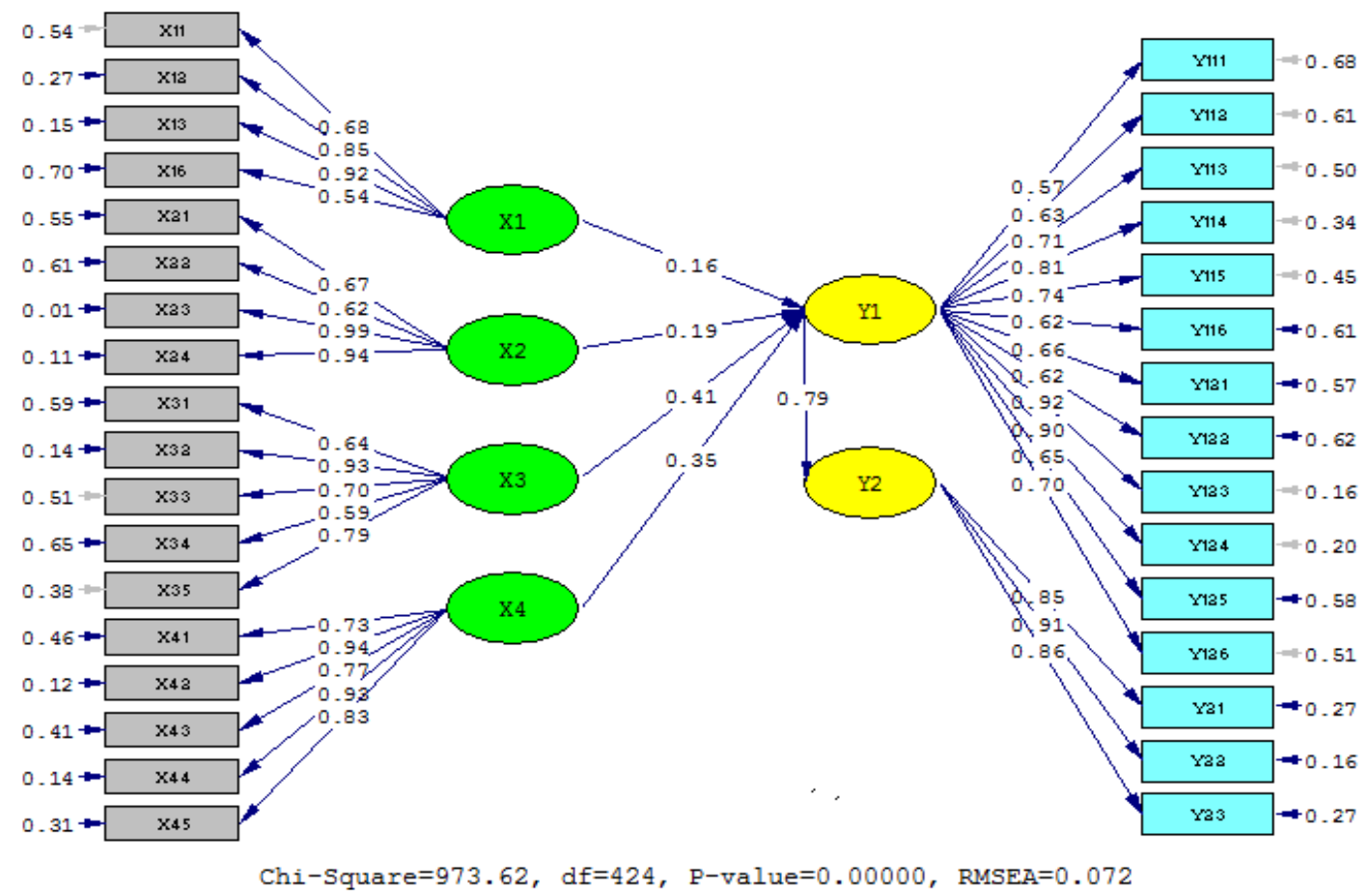

Figure 1. The loading factor of SEM model for digital natives students

In figure 1 it can be seen that information seeking behaviour of digital natives students is influenced most strongly by environment variable (0.41), and the most powerful indicator of that variable is the availability of information (0.93). Furthermore, the success of getting information is influenced most strongly by the information seeking behavior indicator by asking the printed information to the superiors (0.41) and the indicator requesting digital information to the superiors (0.92).

Based on the SEM model above, an information seeking behaviour model for IPB University digital natives students was developed. The model is presented in Figure 2. 


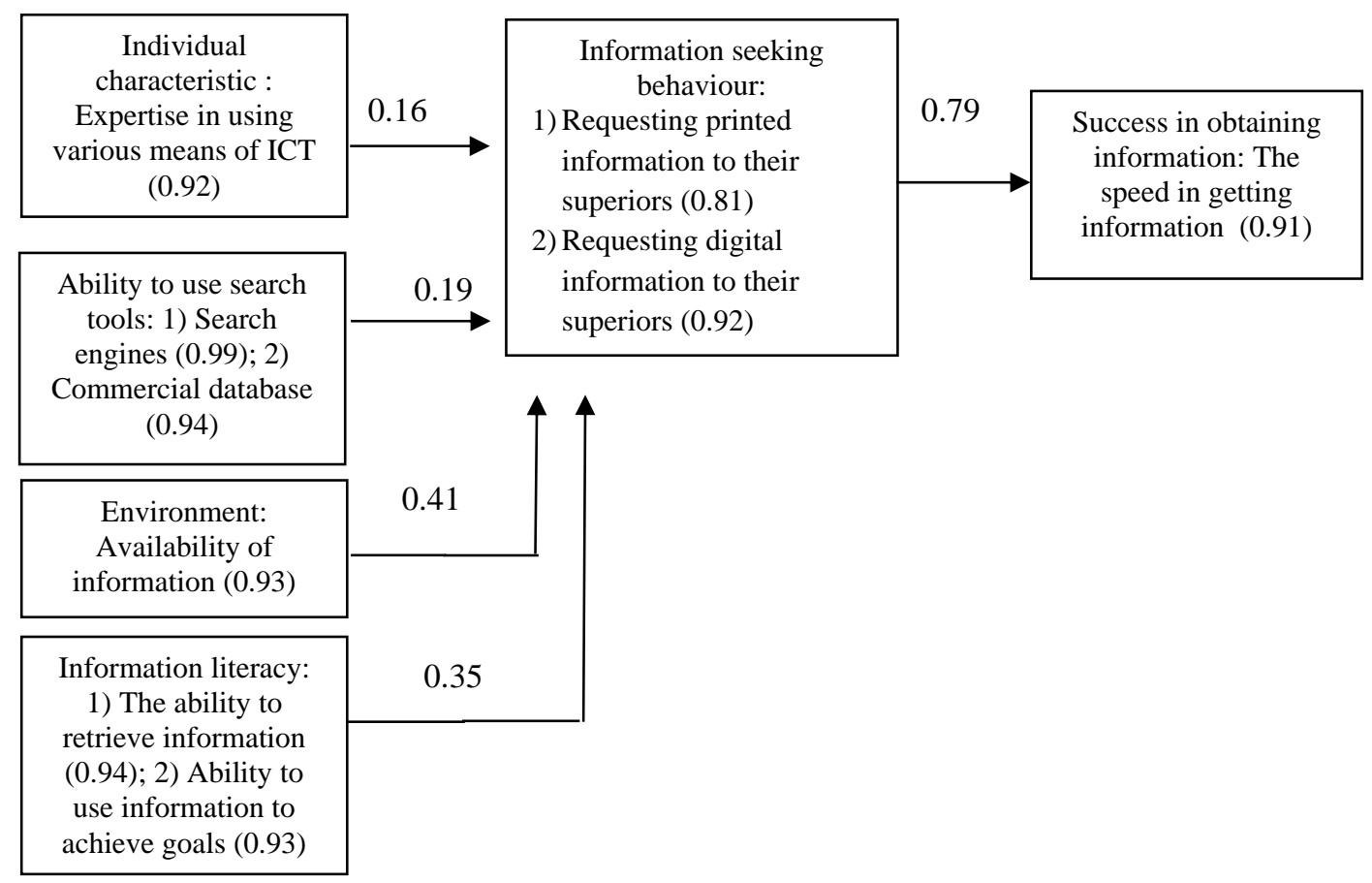

Figure 2. Information seeking behaviour model for IPB University digital natives students

Data processing using SEM for digital immigrant students of IPB University are presented in Figure 3. Due to the small sample size of digital immigrant students, the Partial Least Square (PLS) of SEM model was used.

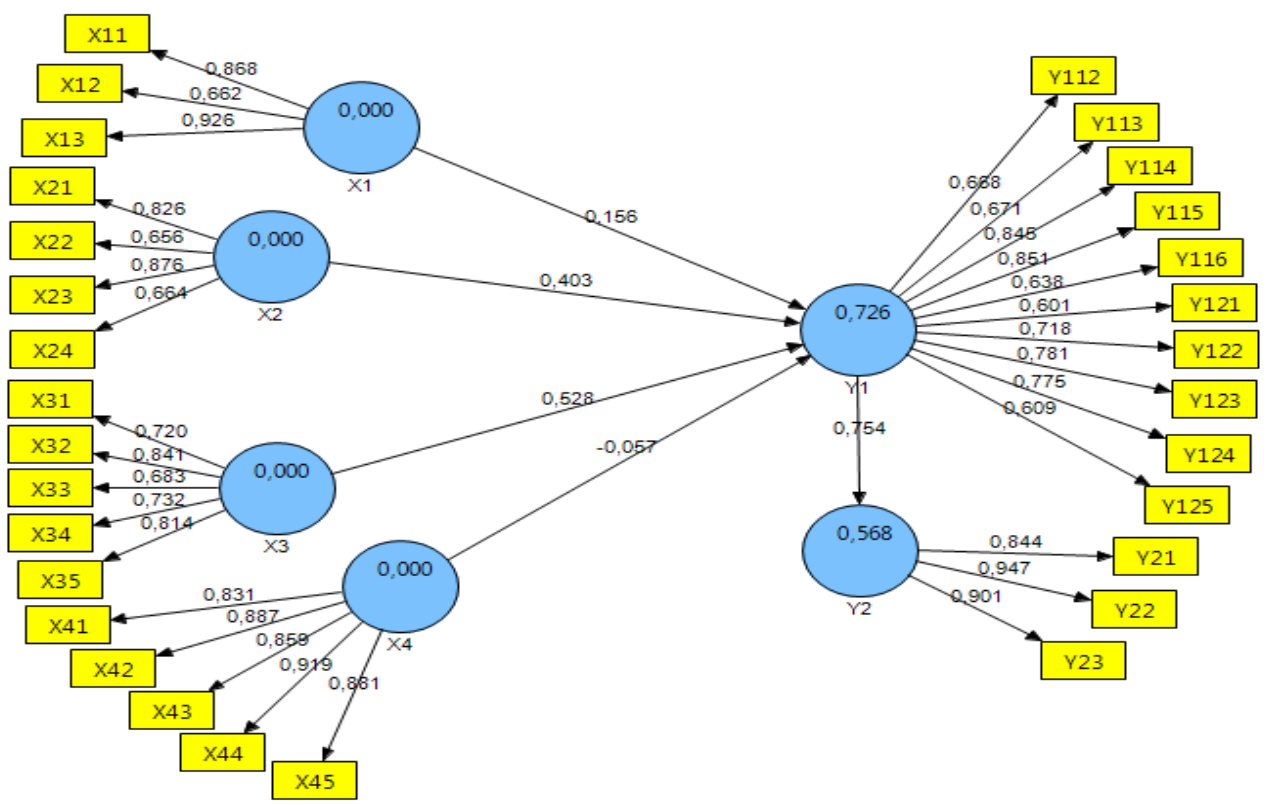

Figure 3. Loading factor for final measurement model of information seeking behaviour of digital immigrant students

Figure 3 shows that individual characteristic variable $\left(\mathrm{X}_{1}\right)$ and information literacy variable $\left(\mathrm{X}_{4}\right)$ do not significantly influence the information 
seeking behaviour variable $\left(\mathrm{Y}_{1}\right)$ of digital immigrant students. The most powerful variable influencing information seeking behaviour is the environment variable (0.53), and the most dominant indicator of that variable is the availability of information (0.84). The success of getting information is strongly influenced by information seeking behaviour indicators by requesting printed information from friends (0.85) and requesting digital information to the superiors (0.78).

Based on the SEM model above, the information seeking behaviour model of the IPB University digital immigrant students was developed. The model is presented in Figure 4.

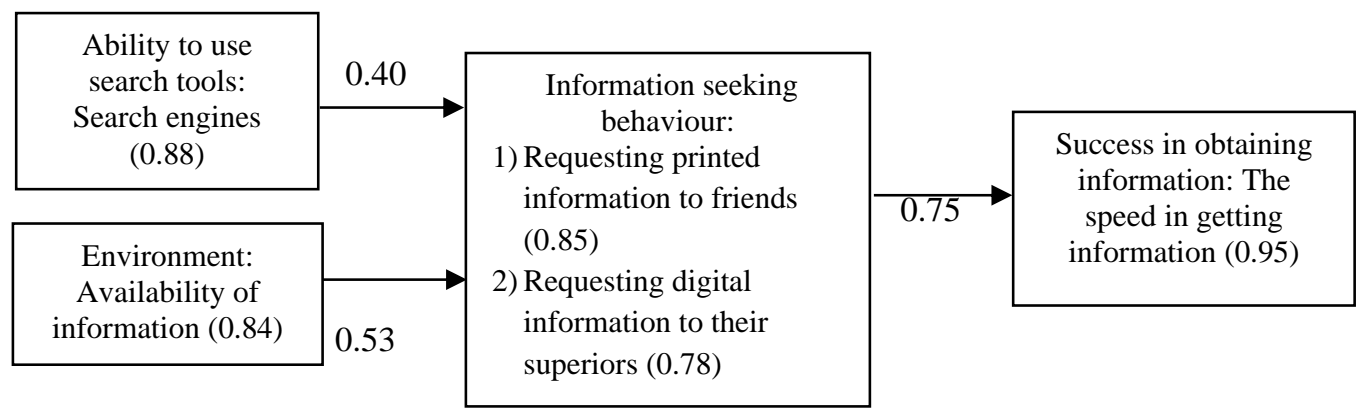

Figure 4. Model of information seeking behaviour of digital immigrant students

\section{Discussion}

The model of information seeking behaviour of IPB University digital natives students (Figure 2) shows that information seeking behaviour is strongly influenced by environmental variables, and the strongest indicator is the availability of information. The dominant factors of information seeking behaviour for digital natives students is printed information and digital information requests to their superiors. For students, their dominant superior in the learning process is lecturer, because lecturer is the best source of knowledge and the significant factor in students' achievement and educational improvement. Thus it is clear that the high availability of information will highly affect the information seeking behaviour of digital natives student. Information seeking behaviour is positively correlated with innovative behaviour (Zhong et al., 2018).

The dominant factors in requesting printed information and digital information to their superiors/lecturers on the one hand shows the caution of digital natives students in using abundant information on the internet, but on the other hand shows they are very dependent on lecturers and not actively seeking information independently. Digital native generation utilizes high-level technology in their everyday life, but very few of them use technology for their learning purposes (Çoklar, 2017). Çoklar's statement could be an explanation of the dependence of digital natives students on providing information from lecturers.

Figure 1 shows the lowest value is $Y_{111}(0.57)$, it is the indicator for borrowing books from the IPB University Library. Another low indicator is for $Y_{112}(0.63)$, which is using the IPB Library collections in the library. In addition, the value of $Y_{121}$ is quite low (0.66), which is the indicator for searching digital information in the IPB University Library. Thus the IPB University Library is not a reference center for digital natives students. They need recommendations from lecturers regarding the sources of information that they are referring to. The library must explore methods how to communicate and interact with digital 
natives, while simultaneously librarian competencies in utilizing the information technology continue to be improved (Allen \& Taylor, 2017).

With reference to such findings, the Library of IPB University should aggressively send information about its collection to the lecturers, so that the lecturers recommend students to use various sources of information available in the library. Çoklar et al. (2017) concluded that lecturers have an important role in promoting students to use various online information resources for learning. In addition, libraries need to carry out promotions that attract the interest of the digital natives generation to take advantage of library collections. The library needs to hold book review competitions with attractive prizes. Various activities that attract students to come to the library need to be held, such as book author meetings, animation making workshops, comic-making workshops, and others.

Due to time management of the life skills IPB students are expected to acquire during their time at university and dealing with workload, IPB University students enjoy a rather unique way of life. At the beginning of the semester students can do other activities rather than their academic assignment. Immediately when they have to attend full course and tight laboratory works, they will concentrate on their course assignments, completing laboratory reports and other literary works. They will not carry out any other tasks. Therefore librarians should establish collaborative relationship with the lecturers who will assign the students reading books or journal articles related to certain lecturer courses. Librarians need to provide a video or multimedia package that discusses the latest findings in a particular field, and invites students and lecturers to watch together. The library also needs to invite international experts, especially authors of best-seller books, supported by the library material vendors. Thus the scientific programs planned by the library will be accepted as the heartbeat of its academic institution.

Model of information seeking behaviour of IPB University digital immigrant students (Figure 4) shows almost the similar results. The model revealed that the information seeking behaviour is influenced by the dominant of environmental variable (0.53), and the dominant indicator is the availability of information (0.84). However, the study found a substantial difference in the information seeking behaviour, the dominant indicator which is digital immigrant students requested their printed information to friends (0.85), while for their digital information is equally similar they requested to their superiors (0.78). The digital immigrant is a person born before the massive introduction of digital technology but accepting digital technology as part of the life. The digital immigrant students are graduate students and they are over 25 years old. Their scientific mastery has been higher than that of the undergraduate students, so that they can rely on their friends to get printed sources of information, not necessarily relying on their superiors/lecturers. The digital immigrant students' dependence on the Library is low, the evidence is expressed by $\mathrm{Y}_{112}$ indicator, the low level of reading printed library collections in the library (0.688), and by $\mathrm{Y}_{121}$ indicator, the lowest level of looking for digital information of IPB University Library collections (0.601). Students often do not know the available resources in the library (Liu et al., 2018).

Libraries have to promote themselves aggressively. Ideally, promo-tional activities for library resources needs to be framed within strategic plan. A large monitor is required to be installed at the front of the library to show the cover of new books along with its table of contents, so that 
passing students are interested to see and check the library collection, and the news will be spread to other students. The monitor should be touch-screen and students can scroll back or forward to a specific screen. The same material also needs to be displayed on the web of the Library and can be accessed on a mobile basis, so that from anywhere and anytime the academics of IPB can see all the new books. The use of mobile technology to access e-resources with friendly interfaces needs to be continuously developed in college libraries (Allen \& Taylor, 2017). The book displayed is not only new books, but when certain topics are viral, the Library needs to display collections related to the problem. Journal articles related to viral issues can also display the article title, journal title and article abstract on the same media.

Information literacy training is needed by digital natives students, especially in the capacity to retrieve information and use the information to achieve goals. Loh \& Mansor's (2010) study revealed that training in information literacy effectively increases student academic self-efficacy and learning performance. Generally digital natives students still have difficulty in determining potential keywords for the topic to be retrieve. Thus librarians need to organize training program on identifying keywords using a thesaurus. Petermanec \& Šebjan (2017) report concluded information literacy skills had strengthened the effectiveness of academic research and the graduates who have mastered the information literate have better job opportunities. Librarians also need to train the digital natives students how to make citations from the other resources, to avoid plagiarism in their research papers. Bartol et al. (2018) in their study revealed that students did not aware of the importance of synthesisanalysis procedures in consulting different sources of information, and using them in their literacy works. Petermanec \&Šebjan (2017) also suggested that librarians need to pay attention to student skills in evaluating and using information appropriately, because it is the most complex component in information literacy, and is the lowest component students have. Shaari, Sidek \& Badzri (2012) suggested the shift in the information literacy training which focus on the specific resources of information into the uses of information in critical thinking. Information literacy training is important for students, as it will provide them the skills to find and utilize information correctly and independently. According to Dubnjakovic (2018) producing scientists require special approach to encourage them to become selfmotivated in searching for information independently.

For digital immigrant students, especially the old age students, special training course to utilize of various search engines and meta search engines for retrieving information on the web should be organized for them. However, digital immigrant students are advised to use a licensed database, as researches on favoring the use of some systems found out that advanced search provides more precise results and guaranteed success in the search (Calhoun et al., 2009).

Times have changed, in our today's interrelated world, information and communication technology (ICT) is extensively used by people and it affects our lives everyday. The academic activities need to use ICT to facilitate teaching, learning and other academic activities. ICT have been employed in information services due to their ability to provide high speed and effective access. In the behavioural model of seeking information from IPB University students, both digital natives and digital immigrants, the success of getting information is dominated by the speed of 
getting information indicators. There is a lot of work to do for IPB university students, they really need that the information should be disseminated much faster, to enable them to finalize their assignments on time. Therefore the development of digital collections is the right choice, because once the purchase transaction is complete, digital collections can be directly accessed by library users. Sodt \& Summey (2009) stated that libraries face the world that is constantly changing along with the increasingly expectations of users as well. Today's libraries must be flexible and always want to try something new. It has become essential for libraries to meet 21 st century user needs and demands by implementing the library 4.0 as described by Noh (2015) by keywords intelligent, maker-space, context-aware technology, open source, big data, cloud service, augmented reality, state-of-the-art display, and librarian 4.0.

\section{Conclusion}

IPB University students have a lot of assignments and tight practicum schedules to do, so the availability of appropriate information is really important for both digital natives and immigrant digital students to complete their assignments. For digital native students the role of lecturers is very dominant in obtaining their printed information and digital information. Whereas for immigrant digital students, friends play dominant role in obtaining printed information, while lecturers are dominant in obtaining their digital information. The getting information quickly is the successful indicators for obtaining information. Thus the library needs continue to acquire the library collection, both by purchasing or being accessible to open access publications which are now increasingly available on the internet.

The IPB University Library should developing effective forms of colla- boration between academics and library staff, so that the utilization of the information resources available in the library will be maximized. In addition, the library need intensive link with the lecturers on the availability of the latest books in the library for their students. The library must promote its collection aggressively using a web that can be accessed on a mobile basis. In addition, the Library will organize scientific events that make the heart of scientific activities take place in the library.

Information literacy trainings are very important for the IPB University students. The course will train students especially the strategy to retrieve information resources and how to use the information, in order to help students produce research papers. Basically information literacy programmes are action oriented, while helping to solve student's work process, to write clearly, logically and effectively of both practical reports, and other final assignments.

\section{References}

Bartol, T., Dolničar, D., Podgornik, B.B., Rodič, B., \& Zoranovič, T. (2018). A comparative study of information literacy skill performance of students in agricultural sciences. The Journal of Academic Librarianship, 44, 374-382.

https://doi.org/10.1016/j.acalib.20 18.03.004.

Cain, S. (2018). Nearly 130 public libraries closed across Britain in the last year. The Guardian, Fri 7 Dec. https://www.theguardian.com/boo ks/2018/dec/07/ nearly-130public-libraries-closed-acrossbritain-in-the-last-year

Calhoun, K., Cantrell, J., Gallagher, P., \& Hawk, J. (2009). Online catalogs: What users and librarians want. Dublin, Ohio: OCLC. Retrieved from https://www.oclc.org/content/dam /oclc/reports/onlinecatalogs/fullre port.pdf 
Case, D.O. (ed.) (2012). Looking for information: A survey of research on information seeking, needs, and behavior. 3rd ed. Bingley: Emerald Group.

Çoklar, A.N., Yaman, N.D. \& Yurdakul, I.K. (2017). Information literacyand digital nativity as determinants of online information search strategies. Computers in Human Behavior, 70, 1-9. http://dx.doi.org/10.1016/j.chb. 2016.12.050

Dubnjakovic, A. (2018). Antecedents and consequences of autonomous information seeking motivation. Library and Information Science Research, 40, 9-17.

https://doi.org/10.1016/j.lisr.2018. 03.003 .

Ford, N. (2015). Introduction to information behaviour. London: Facet Publishing.

Kuhlthau, C.C. (2016). Information search process. RUTGERS School of Communication and Information. http://wp.comminfo.rutgers.edu/ ckuhlthau/information-searchprocess/

Liu, J., Zamir, H., Li, Y., \& Hastings, S.K. (2018). Search systems and their features: What college students use to find and save information. Library and Information Science Research, 40, 118-124. doi: doi.org/10.1016/jlisr.2018. 06.002

Loh, K.H. \& Mansor, Y. (2010). Impact of information literacy training on academic self-efficacy and learning performance of university students in a problem-based learning environment. Pertanika Journal of Social Science \& Humanities. 18(S): 121-134.

Noh, Y. (2015). Imagining library 4.0: Creating a model for future libraries. The Journal of Academic Librarianship. 41: 786-797. http://dx.doi.org/10.1016/j.

acalib.2015.08.020.

Petermanec, Z. \& Šebjan, U. (2017).

Evaluation components of

information literacy in

undergraduate students in Slovenia:

An experimental study. Library \&

Information Science Research. 39: 69-75.

http://dx.doi.org/10.

1016/j.lisr.2017.01.009.

Shaari, L.R.M., Sidek, H.F. \& Badzri, S. (2012). Information skill course at UKM library. UKM Teaching and Learning Congress 2011. ProcediaSocial and Behavioral Sciences. 59: 370375.

doi:10.1016/j.sbspro.2012.09.288.

Sodt, J.M. \& Summey, T.P. (2009).

Beyond the library's walls: Using library 2.0 tools to reach out to all users. Journal of Library

Administration. 49(1-2): 97-109. http://dx.doi.org/10.1080/0193082 0802312854.

West, R. \& Turner, L.H. (2013). Pengantar Teori Komunikasi : Analisis dan Aplikasi. Maer, MND, translator; Setyaningsih, N, editor. Jakarta: Salemba Humanika.

Original title: Introducing Communication Theory: Analysis and Application. 3rd ed.

Wilson, T.D. (1999). Models in information behaviour research. Retrieved from http://informationr.net/tdw/publ/ papers/1999JDoc.html

Zhong, Z., Hu, D., Zheng, F., Ding, S., \& Luo, A. (2018). Relationship between information-seeking behavior and innovative behavior in Chinese nursing students. Nurse Education Today, 63, 1-5. https://doi.org/10.1016/j.nedt. 2018.01.004 